\title{
SCREENING OF BIOACTIVE COMPOUNDS FROM MARINE SPONGES COLLECTED FROM KOVALAM, CHENNAI
}

\begin{abstract}
YUVARANI THAMBIDURAI ${ }^{1}$, SUDARSANAM D ${ }^{2 *}$, HABEEB SKM ${ }^{3}$, JOE K KIZHAKUDAN ${ }^{4}$
${ }^{1}$ Department of Biotechnology, D.G. Vaishnav College, Arumbakkam, Chennai, Tamil Nadu, India. ${ }^{2}$ Department of Advanced Zoology and Biotechnology, Medical Lab Technology and Biomedical Instrumentation Science Head, School of Genomics and Bioinformatics, Loyola College, Chennai, Tamil Nadu, India. ${ }^{3}$ Department of Genetic Engineering, School of Bioengineering, SRM University, Kattankulathur, Chennai, Tamil Nadu, India. ${ }^{4}$ Principal Scientist, CMFRI, CIBA Campus, Raja Annamalai Puram, Chennai, Tamil Nadu, India. Email: dsloy2003@gmail.com
\end{abstract}

Received: 27 January 2017, Revised and Accepted: 20 February 2017

\section{ABSTRACT}

Objective: This study is designed to hunt for the presence of bioactive compounds from three marine sponges collected from Kovalam.

Methods: Zoochemical analysis is performed to screen for the presence of secondary metabolites. Based on those results, only two sponges which showed a significant presence of secondary metabolites has been subjected to gas chromatography-mass spectrometry (GC-MS) analysis to identify the unknown chemical compounds present in those sponges.

Results: On analyzing the results, two sponges, namely, Dysidea herbacea and Sigmadocia pumila, has shown a significant presence of secondary metabolites while the third sponge Acanthella elongata have shown moderate presence of secondary metabolites. Since the first two sponges results are remarkable, these two samples have been subjected to GC-MS analysis to separate and identify the unknown chemical compounds present in the sample.

Conclusion: Samples, namely, D. herbacea and S. pumila, indicated the presence of several components. From both the sponges, eleven different secondary metabolites were identified by GC-MS. Most of these compounds are widely used in cosmetic, pharmaceutical, and other industries and therefore a vital source for industrial biotechnology and related products in healthcare and skincare.

Keywords: Dysidea herbacea, Sigmadocia pumila, Acanthella elongata, Secondary metabolites, Gas chromatography-mass spectrometry analysis, Bioactive compounds.

(C) 2017 The Authors. Published by Innovare Academic Sciences Pvt Ltd. This is an open access article under the CC BY license (http://creativecommons. org/licenses/by/4. 0/) DOI: http://dx.doi.org/10.22159/ajpcr.2017.v10i5.17347

\section{INTRODUCTION}

Marine diversity is so high that majority of the living organisms are yet to be characterized morphologically and chemically [1]. Marine flora and fauna has kept scientists hooked up to look for new avenues for chemical research. Very less proportion of marine species has been studied [2]. Sponges (phylum porifera) are marine invertebrates, known to be multicellular and immobile but sessile [3]. These are a vital source for the researchers to look for novel bioactive compounds [4]. About 4851 compounds which are $30 \%$ of all marine natural products were discovered thus far; making them most prolific marine compound producers as nearly 200 new compounds were reported every year [5].

Infectious microorganisms evolve and develop resistance to existing pharmaceuticals; marine sponges provide novel leads against bacterial, fungal, and viral diseases [6]. Symbiotic relationship with various microorganisms makes them play vital roles such as photosynthetic carbon fixation, nitrification, and nitrogen fixation [7]. It has been reported that the metabolites synthesized by these symbionts could well become an ideal and vital source for the discovery of new drugs [8]. Some of the marine sponges are also known to have cosmetics activities such as anti-aging and anti-wrinkling effects, tyrosinase and metalloproteinase inhibition, and ultraviolet defense. Sponges are used to clean body, face as they soak up and hold more water. They are also used to clean insightful baby skin and whitening compounds [9]. Numerous studies have reported potential cytotoxic, antifungal, antibacterial, anti-inflammatory, and antioxidant activities from the sponges extracts [10-17].

Therefore, in this study, we have collected few sponges from the seashores on the outskirts of Chennai and have performed zoochemical characterization to reveal the presence of secondary metabolites, followed by gas chromatography-mass spectrometry (GC-MS) to identify major chemical compounds present in the samples.

\section{METHODS}

\section{Sponge collection}

Three species of marine sponges were collected from seashores of Kovalam, Kanchipuram, Tamil Nadu, with the help of Dr. Joe K. Kizhakudan, Principal Scientist from Central Marine Fisheries and Research Institute. Taxonomic identification of the samples was done and certified by Dr. Sivaleela, Scientist from Zoological Survey of India (ZSI). The samples were identified as Dysidea herbacea, Sigmadocia pumila, and Acanthella elongata (Fig. 1). Samples were preserved in ice boxes and maintained at $-20^{\circ} \mathrm{C}$ until the experimental process. Voucher specimens preserved at $75 \%$ methanol was deposited at ZSI.

\section{Extraction procedure}

Five gram of the shade dried powdered sample was extracted with dichloromethane $(100 \mathrm{ml})$ and methanol $(100 \mathrm{ml})$ at room temperature overnight on a shaker. The extracts were filtered through filter paper and concentrated in vacuum and were stored at $-20^{\circ} \mathrm{C}$ for further zoochemical analysis.

\section{Zoochemical analysis}

Individual tests were performed to identify the presence of common zoochemicals using conventional methods. To determine the presence of carbohydrate, $1 \mathrm{ml}$ of Molisch's reagent and few drops of concentrated sulfuric acid were added to $2 \mathrm{ml}$ of sponge extract [18]. The presence of tannin was confirmed by adding $2 \mathrm{ml}$ of $5 \%$ ferric chloride to $1 \mathrm{ml}$ of sponge extract [19]. To $2 \mathrm{ml}$ of sponge extract, $2 \mathrm{ml}$ of distilled 
water was added and shaken in a graduated cylinder for 15 minutes lengthwise to determine the presence of saponins [20]. Addition of $1 \mathrm{ml}$ of $2 \mathrm{~N}$ sodium hydroxide to $2 \mathrm{ml}$ of sponge extract determined the presence of flavonoids. The presence of cardiac glycoside was confirmed with the addition of $2 \mathrm{ml}$ of glacial acetic acid and few drops of $5 \%$ ferric chloride were added to $0.5 \mathrm{ml}$ of extract, and then, $1 \mathrm{ml}$ of concentrated sulfuric acid. Addition of $2 \mathrm{ml}$ of chloroform was added and concentrated sulfuric acid to $0.5 \mathrm{ml}$ of extract determined the presence of terpenoids. To determine the presence of triterpenoids, $1 \mathrm{ml}$ of Libermann-Burchard Reagent (acetic anhydride + conc.sulfuric acid) was added to $1.5 \mathrm{ml}$ of extract. To determine the presence of phlobatannins and anthraquinones, few drops of $2 \%$ hydrochloric acid and few drops of $10 \%$ ammonia solution respectfully were added to each $1 \mathrm{ml}$ of extract [21]. The presence of alkaloids was confirmed by adding $2 \mathrm{ml}$ of concentrated hydrochloric acid and few drops of Mayer's reagent to $2 \mathrm{ml}$ of sponge extract [22]. Test for quinones was performed by adding $1 \mathrm{ml}$ of concentrated sulfuric acid to $1 \mathrm{ml}$ of extract. Addition of $3 \mathrm{ml}$ of chloroform and $10 \%$ ammonia solution to $2 \mathrm{ml}$ of sponge extract determined the presence of glycosides. To test for the presence of phenol, $2 \mathrm{ml}$ of distilled water followed by few drops of $10 \%$ ferric chloride was added to $1 \mathrm{ml}$ of sponge extract. Addition of $1 \mathrm{ml}$ of $10 \%$ sodium hydroxide to $1 \mathrm{ml}$ of extract determined the presence of coumarins [23]. To confirm the presence of steroids and phytosteroids, $1 \mathrm{ml}$ of sponge extract equal volume of chloroform and few drops of concentrated sulfuric acid were added [24].

\section{Gas chromatography-mass spectrometer analysis}

Five gram freeze-dried sponge sample was extracted with chloroform and methanol in 2:1 ratio. The extract was evaporated under reduced pressure. The extract (500 mg) was chromatographed on a column $(60 \times 2.5 \mathrm{~cm}$ diameter $)$ of silica gel using eluents of increasing polarity from hexane through ether to ethyl acetate. GC-MS analyses were carried out with a GC-MS QP-5000 (Shimadzu Corp.) fitted with a fused silica DB-5 capillary column $(0.22 \mathrm{~mm} \times 30 \mathrm{~m}, 0.25 \mu \mathrm{m}$ film thickness $)$ with helium gas at a flow rate of $1 \mathrm{ml} /$ minute. The sample was injected in the splitless mode (sampling time, 5 minutes). The respective temperatures of the GC injection port and ionization chamber were $290^{\circ} \mathrm{C}$ and $280^{\circ} \mathrm{C}$. Temperature programs for the column oven were as
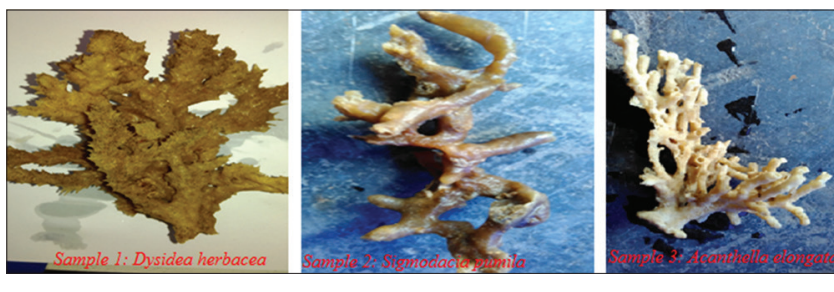

Fig. 1: Images of the collected samples from Kovalam follows: program, $60^{\circ} \mathrm{C}$ for 1 minute, elevated to $130^{\circ} \mathrm{C}$ at $20^{\circ} \mathrm{C} /$ minute, then to $210^{\circ} \mathrm{C}$ at $10^{\circ} \mathrm{C} /$ minute, then to $260^{\circ} \mathrm{C}$ at $10^{\circ} \mathrm{C} /$ minute, then to $300^{\circ} \mathrm{C}$ at $10^{\circ} \mathrm{C} /$ minute; it was finally maintained at $300^{\circ} \mathrm{C}$.

\section{RESULTS AND DISCUSSION}

The sponges which were initially subjected to zoochemical analysis showed their presence for secondary metabolites in different tests which was mentioned in Table 1 for the three sponges $D$. herbacea, $S$. pumila, and $A$. elongata. Tests for phenols (except dichloromethane extract of $S$. pumila) and steroids (except dichloromethane extract of $D$. herbacea) reported positive for these samples. The presence of alkaloids was confirmed in the methanolic extracts. Saponins were reported in all the extract types but dichloromethane extract of $S$. pumila. Flavonoids which are rich sources for various biological properties were able to be traced by the methanolic extracts of $D$. herbacea and S. pumila. On the other hand, both extracts of $D$. herbacea signaled the presence of carbohydrates. Glycosides, cardiac glycosides, terpenoids, coumarins, plobatannins, and anthraquinones were not present in our sponge samples at all. 16 tests for methanolic extracts and 10 for dichloromethane were positive and 58 were negative for 14 tests across three selected species. Overall, a remarkable presence is exhibited in methanol extract when compared to dichloromethane extract.

As the first two samples, namely, D. herbacea and S. pumila, has marked a significant presence of secondary metabolites, these two samples were further taken for GC-MS analysis to separate and identify various components present in the sample. From both the sponges, 11 components were separated at different retention time (RT).

D. herbacea (Fig. 2) revealed the occurrence of components such as cyclohexasiloxane, dodecamethyl at $3.826 \mathrm{RT}$, 3 isopropoxy-1,1,1,7,7,7 hexamethyl 3,5,5-tris (trimethylsiloxy) tetrasiloxane at 4.685 RT, 3-Tosyl sedoheptulose at5.061 RT, cyclooctasiloxane hexadecamethylat6.080RT, 2-(2,4,4,6,6,8,8-heptamethyltetrasiloxan 2 yloxy)-2,4,4,6,6,8,8,10,10nonmethylcyclopentasiloxane at 8.668 RT, 1,1,1,3,5,5,7,7,7-nanomethyl3-(trimethylsiloxy)-tetrasiloxane at $11.962 \mathrm{RT}$, ethanedioic acid bis(trimethylsilyl)ester at $15.414 \mathrm{RT}$, trisiloxane 1,1,1,5,5,5 hexamethyl-3.3-bis(trimethylsilyl)oxy at 21.504 RT, octasiloxane 1, $1,3,3,5,5,7,7,9,9,11,11,13,13,15,15$ hexadecamethyl at 26.827 RT, $1,1,1,3,5,5,5$-heptamethyltrisiloxane at 28.829 RT, 3,6-dioxy 2,4,5,7 tetrasiloctane $2,2,4,4,5,5,7,7$ octamethyl at 29.224 RT. Two compounds, namely, 3 isopropoxy-1,1,1,7,7,7hexamethyl 3,5,5-tris(trimethylsiloxy) tetrasiloxane at 4.685 RT and 3-tosyl sedoheptulose at 5.061 RT are predominant in this sponge sample.

S. pumila (Fig. 3) revealed the presence of cyclopentasiloxane decamethyl at 3.156 RT, cyclohexasiloxane dodecamethyl at 3.827 RT, 3isopropoxy-1,1,1,7,7,7 hexamethyl3,5,5-tris(trimethylsiloxy)

Table 1: Results of the zoo chemical tests for the presence of classes of secondary metabolites in two extracts

\begin{tabular}{|c|c|c|c|c|c|c|c|}
\hline S.No. & Zoo chemical tests & DHM & DHDM & SPM & SPDM & AEM & AEDM \\
\hline 1 & Carbohydrate test & & & & & & \\
\hline 2 & Tannins test & & & & & & \\
\hline 3 & Saponins test & & & & & & \\
\hline 4 & Flavonoids test & & & & & & \\
\hline 5 & Alkaloid test & & & & & & \\
\hline 6 & Quinones test & & & & & & \\
\hline 7 & Glycosides test & & & & & & \\
\hline 9 & Terpenoids test & & & & & & \\
\hline 10 & Phenols test & & & & & & \\
\hline 11 & Coumarins test & & & & & & \\
\hline 12 & Steroids & & & & & & \\
\hline 13 & Phlobatannins test & & & & & & \\
\hline 14 & Anthraquinones test & & & & & & \\
\hline
\end{tabular}

DHM: Dysidea herbacea methanol extract, DHDM: Dysidea herbacea dichloromethane extract, SPM: Sigmadocia pumila methanol extract, SPDM: Sigmadocia pumila dichloromethane extract, AEM: Acanthella elongata methanol extract, AEDM: Acanthella elongata dichloromethane extract, , red color - negative result, green color - positive result 


\section{GCMŚ Mothod: GC: MS: FAME.EXP Sample ID:

\section{TARCET SPECTRUM}

C6.11.2015_EN1510014001 60 (3.829) Cm (68:70.54)
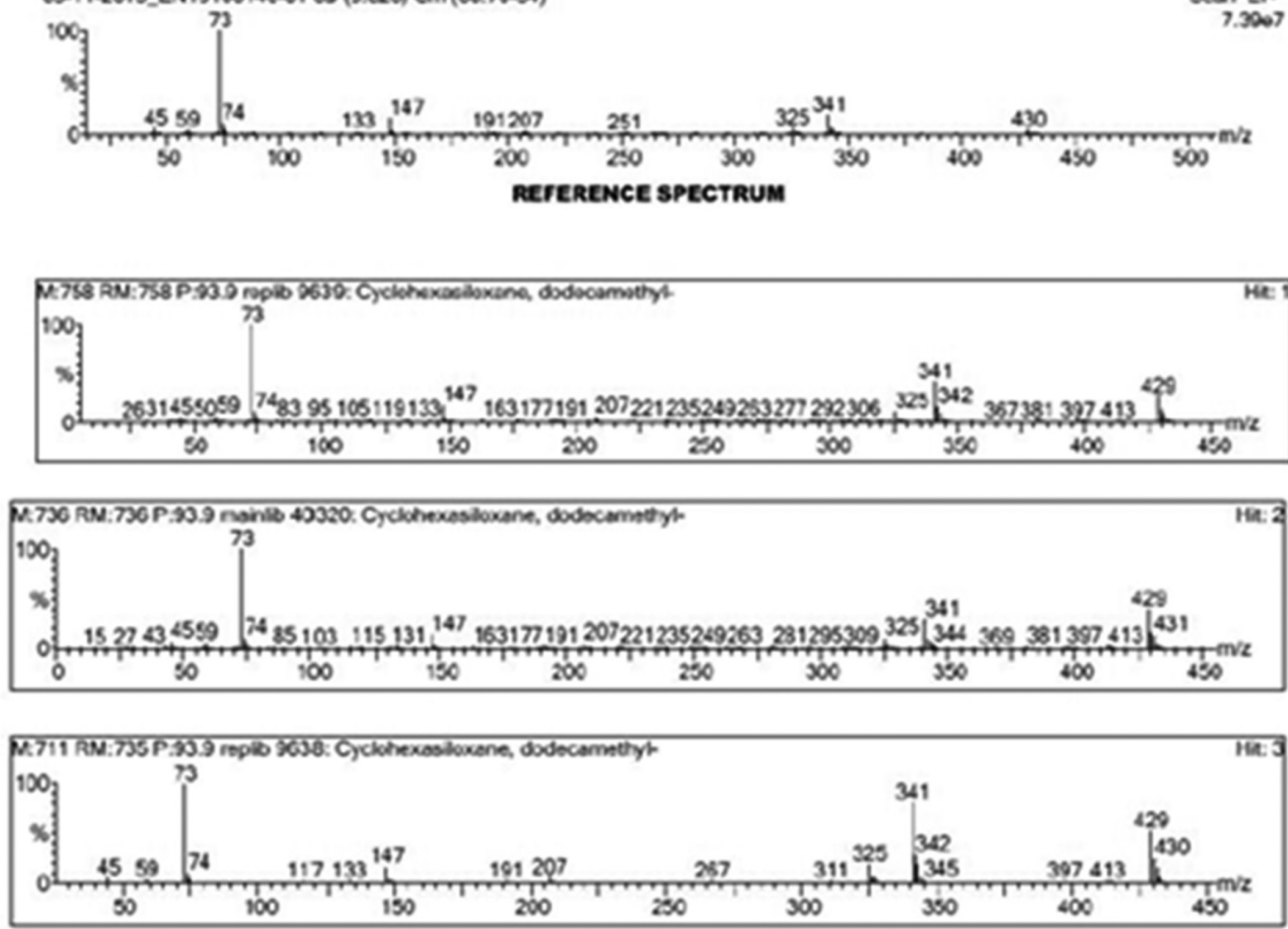

\section{LIBRARY SEARCH HIT LIST}

\begin{tabular}{|c|c|c|c|c|c|}
\hline , Liे & Match & RMatch & Namo & uW & Chemical Forn \\
\hline 1 reolb & 758 & 758 & Goloherasiloxane, dodacametyl. & 444.0 & C12HasOSS6 \\
\hline 2 mairib & 736 & 736 & Codoherasiloxane, dodecamettyl. & 4420 & $\mathrm{Cl} 2 \mathrm{H} 3 \mathrm{OOSS6}$ \\
\hline 3 reolib & 711 & 725 & Ordohexesiloxane, dodocametyl. & 440 & C12HOSOSSO \\
\hline 4 mairib & 610 & 698 & $\begin{array}{l}1,1,1,35,7,9,11,11,11 \text {-Decanetyly. } \\
\text { (timatvisiowherasiocase }\end{array}$ & 490.0 & $\mathrm{C} 13 \mathrm{H} 4205 \mathrm{S7}$ \\
\hline 5 maintb & 596 & 596 & $\begin{array}{l}\text { Heptasloxane, } 1,1,3,3,5,5,7.9,9,11,11,13,13 \\
\text { teradecanethy. }\end{array}$ & 500.0 & $\mathrm{C} 14 \mathrm{H} 4: 05 \mathrm{SB}$ \\
\hline 6 mainitb & 564 & 564 & $\begin{array}{l}\text { Ottriloxano, 1,1,3,3,5,5,7,7,0,0,11,11,13,13,15, 15. } \\
\text { hexedocanethy. }\end{array}$ & 578.0 & $\mathrm{C1} 6 \mathrm{H} 5007 \mathrm{~S}_{8}$ \\
\hline 7 mainilo & 556 & 587 & $\begin{array}{l}\text { Acesc acis, piss(timetrylsilynoryjphosphiny?, } \\
\text { trmethylsily ester }\end{array}$ & 356.0 & C11H29OSPSin \\
\hline 8 mainib & 528 & 562 & 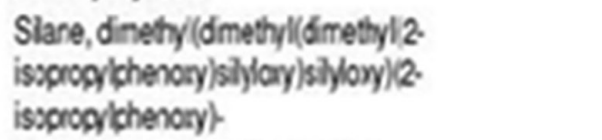 & 476.0 & $\mathrm{C}_{24} \mathrm{H}_{4} \mathrm{O}_{4} \mathrm{~S} 33$ \\
\hline$\theta$ reoplo & 523 & 527 & Heptaslorano, hocadocamothyb & 532.0 & $\mathrm{C}_{16} 6480587$ \\
\hline 10 reolb & 520 & 610 & 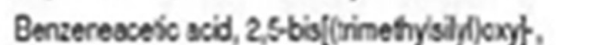 & 3040 & $\mathrm{C}_{17}+32 \mathrm{O}_{4} \mathrm{SS}_{3}$ \\
\hline
\end{tabular}

Fig. 2: Results of gas chromatography-mass spectrometry analysis for the sample Dysidea herbacea 

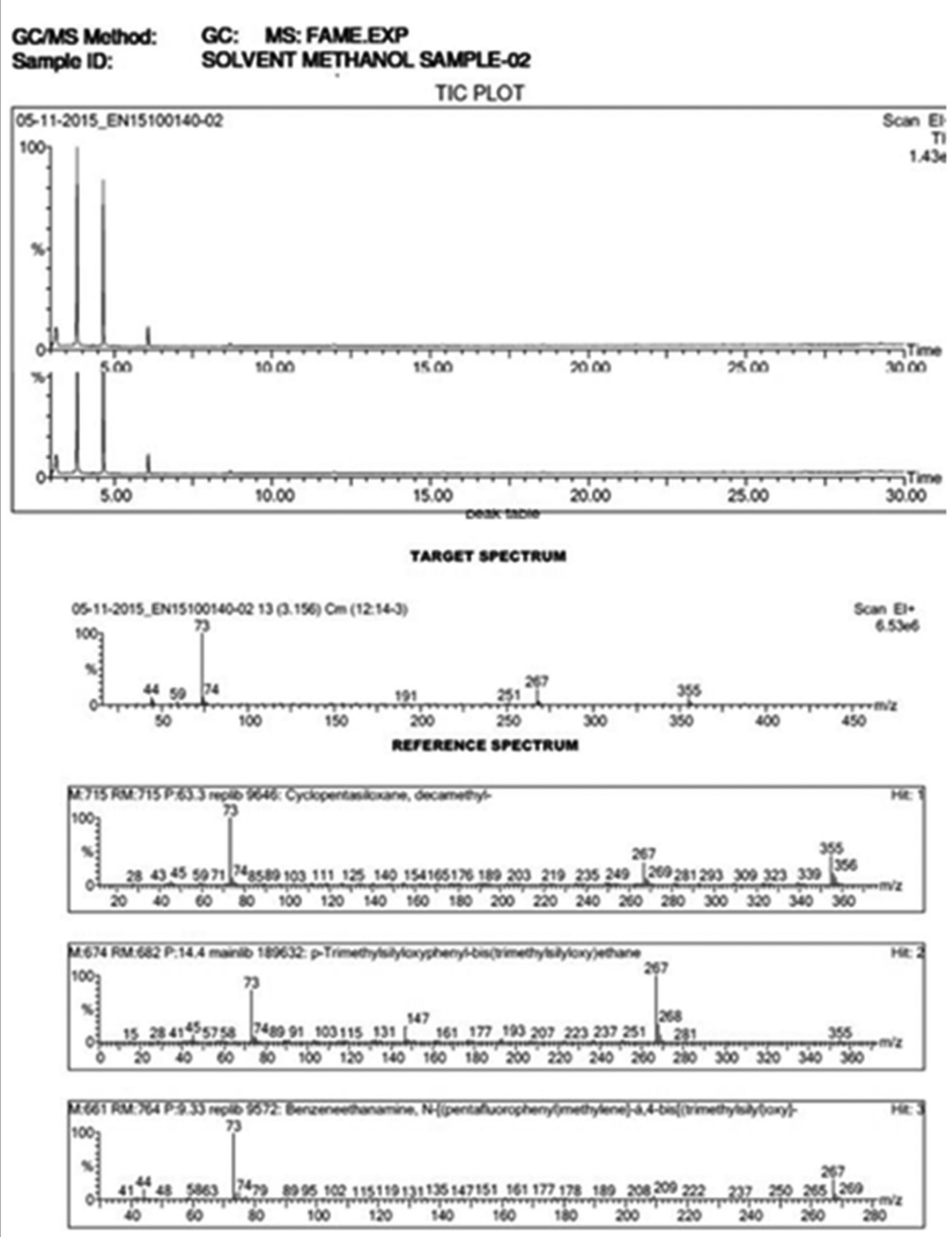

\begin{tabular}{|c|c|c|c|c|c|c|}
\hline \multirow[b]{2}{*}{ - } & \multirow[b]{2}{*}{ its } & \multicolumn{3}{|r|}{ LERARY SEARCH MIT LIST } & \multirow[b]{2}{*}{$\mathbf{M W}$} & \multirow[b]{2}{*}{ Chemical Formuls } \\
\hline & & Match & Ruatch & 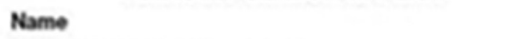 & & \\
\hline 1 & repib & 715 & 715 & Cyclopentasiloxane, decametryb & 390.0 & C10H3OOSSS \\
\hline 2 & mainto & 674 & 602 & 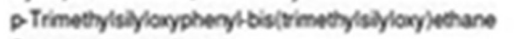 & 970.0 & C17msuOssa \\
\hline 3 & repio & esi & 764 & 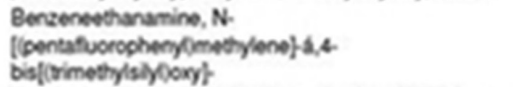 & 475.0 & C21HeEFSNO2S:2 \\
\hline 4 & replo & eas & 756 & 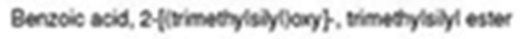 & 2120 & C13н2aOs:2 \\
\hline 5 & mainto & 628 & 697 & Oyclocentasiloxane, decametyl & 970.0 & CichooOssis \\
\hline 6 & replo & 612 & 612 & Cyelogentasiloxame, decamechl & $\boldsymbol{3 9 0 . 0}$ & C10Hooosss \\
\hline 7 & mainlo & 601 & 600 & 2.Hydronmandelc acid, etry ester, \&.TMS & 340.0 & $\mathrm{C}_{16 \mathrm{H}} \mathrm{eO} 4 \mathrm{~S}_{2}$ \\
\hline 8 & replo & 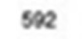 & 678 & 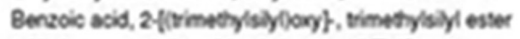 & 2120 & C136eacos:2 \\
\hline$\vartheta$ & mainto & 502 & 67 & 3.Hydrommandelic acid, ethyl ester, \& TMS & 340.0 & $\mathrm{C}_{16 \mathrm{H}} \mathrm{eO} 4 \mathrm{~S} 2$ \\
\hline 10 & replo & 568 & 678 & 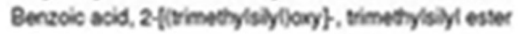 & 2120 & 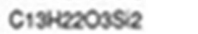 \\
\hline
\end{tabular}

Fig. 3: Results of gas chromatography-mass spectrometry analysis for the sample Sigmadocia pumila 
tetrasiloxane at $4.655 \mathrm{RT}$, acetic acid ([aminocarbonyl]amino)oxo at $4.835 \mathrm{RT}$, hexasiloxanetetradecamethyl at $6.082 \mathrm{RT}$, malonic acid bis(2 trimethylsilyethyl) ester at 8.672 RT, 1,3 dioxolane-2-methanol at 11.958 RT, 1,1,1,3,5,5,7,7,7-nanomethyl-3-(trimethylsiloxy)tetrasiloxane at 15.388 RT, trisiloxane 1,1,1,5,5,5 hexamethyl3.3-bis(trimethylsilyl)oxy at 18.578, cyclotrisiloxanehexamethyl at $28.772 \mathrm{RT}$, and 1,1,1,3,5,5,5-heptamethyltrisiloxane at 29.228 RT. Two compounds, namely, cyclohexasiloxanedodecamethyl at 3.827 RT, 3 isopropoxy-1,1,1,7,7,7 hexamethyl 3,5,5-tris(trimethylsiloxy) tetrasiloxane at $4.655 \mathrm{RT}$ are predominant in S. pumila.

\section{DISCUSSION}

Marine supplies are a potent source for unexplored chemical moieties that may have vital biological and economic properties. Marine diaspora over the years has proven its importance as several of compounds of economic significance are isolated and mass produced across the globe. Very little of these living organisms was studied and therefore provides ample opportunities to hunt for vital substances. Three species chosen here in this study such as D. herbacea, S. pumila, and A. elongata were used to assess zoochemical properties with the help of methanolic and dichloromethane solvents. Both these extracts were able to track many vital secondary metabolites of different importance. Although glycosides, cardiac glycosides, terpenoids, coumarins, phlobatannins, and anthraquinones were not present in any of these extracts, other class of secondary metabolites such as saponins, phenols, steroids, alkaloids, and flavonoids was traced in these samples. Saponins are class of glycosides with soap-like foaming properties produced in abundance in various plant species. This particular property of saponins has led to its utilization as natural emulsifiers in cosmetic industry [25]. Alkaloids are nitrogenous organic compounds produced by variety of organisms such as bacteria, fungi plants, and animals. Alkaloids have wide range of applications in pharmacology including antimalarial, antiasthma, and anticancer. Alkaloids are commonly used in cosmetic industry as one of the ingredient in skin care mixtures. Alkaloids are used for skin protective purposes, against wrinkles, skin tightening extracts, etc [26]. These flavanoids are class of plant pigments commonly used in cosmetics as antioxidant and for soothing actions [27].

Cyclohexasiloxanedodecamethyl (dodecamethylcyclohexasiloxane [D6]) isolated from S. pumila is found to have many industrial applications. This compound is used in the production of silicone polymers, organosilicon substances, and a wide application in personal and household care products. Personal care products such as antiperspirants, skin creams and lotions, skin cleansing product, and hair care products [28].

It is also reported that sponge-associated bacterial extracts have cytotoxicity effect on MOLT4 cell lines by the result of cell cycle analysis hence claimed anticancer activity [29] which suggests sponges could play an active role in anticancer activity. The extract of marine sponge A. globostellata found to possess bioactive properties such as flavonoids, terpenoids, phenolic compounds, and aromatic acids and exhibited a good antioxidant activity [30] also claims that secondary metabolites from sponges could serve as an antioxidant.

3 isopropoxy-1,1,1,7,7,7 hexamethyl 3,5,5-tris (trimethylsiloxy) tetrasiloxane has been reported in many species which include brown rice [31], leaves of Commelina benghalensis $L$, and root and rhizome of Smilax zeylanica. In our study, 3 isopropoxy-1,1,1,7,7,7 hexamethyl 3,5,5-tris (trimethylsiloxy) tetrasiloxane was known to be predominant in two sponges $D$. herbacea and $S$. pumila. Cyclooctasiloxane hexadecamethyl was reported to have antimicrobial property and it was also reported in Oscillatoria species [32] and Solanum nigram [33].

\section{CONCLUSION}

Three different sponges collected from different locations were extracted and various zoochemical tests were performed to identify some of the secondary metabolites produced by them. Samples, namely,
D. herbacea and S. pumila indicated the presence of several components. From both the sponges, 11 different secondary metabolites were identified by GC-MS. Most of these compounds are widely used in cosmetic, pharmaceutical, and other industries, and therefore, a vital source for industrial biotechnology and related products in healthcare and skincare.

\section{ACKNOWLEDGMENT}

This research was done with the help of Dr. Sivaleela, Scientist from ZSI for helping in taxonomic identification of the sponge samples.

\section{REFERENCES}

1. Proksch P, Edrada RA, Ebel R. Drugs from the seas - current status and microbiological implications. Appl Microbiol Biotechnol 2002;59(2-3):125-34.

2. Silinskas RA. Marine Biotechnology and the Third World: Research and Applications. Conference Proceeding Series: Harnessing Biotechnology for the $21^{\text {st }}$ Century. Washington DC: American Chemical Society; 1992.

3. Vacelet J, Duport E. Prey capture and digestion in the carnivorous sponge Asbestopluma hypogea (Porifera: Demospongiae). Zoomorphology 2004;123(4):179.

4. Bhakuni DS, Rawat DS. Bioactive Marine Naturalproducts. New Delhi, India: Springer and Anamaya Publishers; 2005.

5. Blunt JW, Copp BR, Munro MH, Northcote PT, Prinsep MR. Marine natural products. Nat Prod Rep 2010;27(2):165-237.

6. Sagar S, Kaur M, Minneman KP. Antiviral lead compounds from marine sponges. Mar Drugs 2010;8(10):2619-38.

7. Diaz MC, Ward BB. Sponge-mediated nitrification in tropical benthic communities. Mar Ecol Prog Ser 1997;156:97-107.

8. Lu X, Cao X, Liu X, Jiao B. Marine microbes-derived anti-bacterial agents. Mini Rev Med Chem 2010;10(11):1077-90.

9. Uppala L. A review on active ingredients from marine sources used in cosmetics. SOJ Pharm Pharm Sci 2015;2(3):1-3.

10. Newbold RW, Jensen PR, Fenical W, Pawlik JR. Antimicrobial activity of Caribbean sponge extracts. Aquat Microb Ecol 1999;19:279-84.

11. Faulkner DJ. Highlights of marine natural products chemistry (19721999). Nat Prod Rep 2000;17(1):1-6.

12. Sipkema D, Franssen MC, Osinga R, Tramper J, Wijffels RH. Marine sponges as pharmacy. Mar Biotechnol (NY) 2005;7(3):142-62.

13. Rangel M, Sanctis B, Freitas JC, Polatto JM, Granato AC, Berlinck RG, et al. Cytotoxic and neurotoxic activities in extracts of marine sponges from southeastern Brazilian coast. J Exp Biol Ecol 2001;262:31-40.

14. Touati I, Chaieb K, Bakhrouf A, Gaddour K. Screening of antimicrobial activity of marine sponge extracts collected from Tunisian coast. J Med Mycol 2007; 17:183-6.

15. Ferreira M, Cabado AG, Chapela MJ, Fajardo P, Atanassova M, Garrido A, et al. Cytotoxic activity of extracts of marine sponges from NW Spain on a neuroblastoma cell line. Environ Toxicol Pharmacol 2011;32:430-7.

16. Lakshmi V, Mishra SK, Srivastava S, Chaturvedi A, Srivastava MN, Shukla PK. Antifungal activityof marine sponge Haliclona exigua (Krikpatrick). J Med Mycol 2010;20:31-3.

17. Li H, Shigeki S, Fusetani N. Simple antifungal metabolites from a marine sponge, Halichondria sp. Comp Biochem Physiol Part B Comp Biochem 1994;107:261-4.

18. Sofowora A. Medicinal Plants and Traditional Medicinal in Africa. $2^{\text {nd }}$ ed. Sunshine House, Ibadan, Nigeria: Spectrum Books Ltd., Screening Plants for Bioactive Agents; 1993. p. 134-56.

19. Harborne JB. Phytochemical Methods: A Guide to Modern Techniques of Plant Analysis. $3^{\text {rd }}$ ed. New York: Chapman and Hall; 1973. p. 279.

20. Smolenski SJ, Silinis H, Farnsworth NR. Alkaloid screening. V. Lloydia 1974;37:506-36.

21. Jana S, Shekhawat GS. Phytochemical analysis and antibacterial screening of in vivo and in vitro extracts of Indian medicinal herbs: Anethum graveolens. Res J Med Plants 2010;4(4):206-12.

22. Ayoola GA, Coker AB, Adesegun SA, Adepoju-Bello AA, Obaweya K, Ezennia EC, et al. Phytochemical screening and antioxidant activities of some selected medicinal plants used for malaria therapy in Southwestern Nigeria. Trop J Pharm Res 2008;7(3):1019-24.

23. Sureshkumar CA, Varadharajan R, Muthumani P, Meera R, Devi P, Kameswari B. Pharmacognostic and preliminary phytochemical investigations on the stem of Saccharum spontaneum. J Pharm Sci Res 2009;1(3):129-36 
24. Kolawole OM, Oguntoye SO, Agbede O, Olayemi AB. Studies on the efficacy of Bridelia ferruginea Benth.bark extract in reducing the coliform load and BOD of domestic waste water. Ethnobot Lealf 2006;10:228-38.

25. Massiot G, Lavaud C, Besson V, Men-Olivier LL, van Binstt G. Saponins from aerial parts of alfalfa (Medicago sativa). J Agric Food Chem 1997;39:78-82.

26. Available from: http://www.dermaviduals.com/cms/upload/Publikationen english/KI-12-14-Alkaloide-engl.pdf.

27. Arct J, Pytkowska K. Flavonoids as components of biologically active cosmeceuticals. Clin Dermatol 2008;26(4):347-57.

28. Available from: http://www.dowcorning.co.kr/ko KR/content/about/ aboutehs/EHSPortalFiles/GPS_Safety_Report_540-97-6_D6.pdf.

29. Karwati A, Nomura J, Ramli N, Wahyudi AT. Cytotoxicity of crude extract from sponge-associated bacteria against molt4 leukemic cell lines through apoptosis. Int J Pharm Pharm Sci 2015;7(12):246-9.

30. Sugappriya M, Sudarsanam D. Free radical screening activity of marine sponge Aurora globostellata. Asian J Pharm Clin Res 2016;9(4):210-2.

31. Krishnaveni M. GC-MS/MS analysis of brown rice. Asian J Pharm Clin Res 2015;8(5):73-75

32. Sutharsana SL, Sankareswaran SK, Muthuselvam P, Ramanathan G. Characterization and anticancer activity evaluation of fatty acid metabolite from marine cyanobacteria in the Southwest coast of Tamil Nadu, India. J Chem Pharm Res 2016;8(1S):160-9.

33. Jasim H, Hussein AO, Hameed IH, Kareem MA. Characterization of alkaloid constitution and evaluation of antimicrobial activity of Solanum nigrum using gas chromatography mass spectrometry (GC-MS). J Pharmacogn Phytother 2015;7(4):57-73. 